\title{
PERAMALAN JUMLAH KLAIM DENGAN MEMBANDINGKAN METODE DOUBLE EXPONENTIAL SMOOTHING DARI BROWN DAN DOUBLE EXPONENTIAL SMOOTHING DARI HOLT
}

\author{
Nayla Desviona $^{1}$, Trima Asriyati ${ }^{2}$, Ditayatul Rahayu ${ }^{3}$, Bangkit Prima Yudha ${ }^{4}$, \\ Kamid $^{5}$, Gusmanely ${ }^{6}$ \\ 1,2,3,4 Institut Teknologi dan Bisnis Muhammadiyah Purbalingga \\ ${ }^{5,6}$ Program Studi Matematika Fakultas Sain dan Teknologi Universitas Jambi
}

Email Koresponden : nayladesviona02@gmail.com

\begin{abstract}
Time series model is that model uses to prediction the future with the past data, one of example of time series is exponential smoothing. Exponential smoothing is repair procedure where's it done continuely at forecasting by new data. In this research Exponential Smoothing metode applied to forecasting amount of claim in Health BPJS at jambi with use the data since january 2018 until Juli 2021, the steps use to get output of research there are 4 steps, these are 1) Data Identification, 2) Modeling, 3) Forecasting, 4) Evaluation of Forecasting Result with MAE(Mean Absolute Error) and MSE (Mean Square Error). Brown's model for PNS class 1: $F_{9+m}=161,65+1,3126 m$, PNS class $2: F_{9+m}=67,997+1,635 \mathrm{~m} \mathrm{NON}$ PNS class $1: F_{9+m}=182,5+12,392 m$, NON PNS class $2: F_{9+m}=186+$ 0,831. Holt's model for PNS class 1: $F_{9+m}=164,917+1,43009 \mathrm{~m}$,.PNS class $2: F_{9+m}=164,917+1,4301 m$, NON PNS class $1: F_{9+m}=189,59+2,7168 m$ and NON PNS class $2: F_{9+m}=190,01+1,703 \mathrm{~m}$. Both of two metodes have similar good performance. but Holt's metode has error value (MAE) more little then Brown's metode. this thing is so important for looked considering its importance a forecasting for he best increase quality and contribution by Health BPJS at Jambi staff for future.
\end{abstract}

Keyword: Claim, Exponential Metode, Brown's Double Exponential Smoothing Brown, Holt's Double Smoothing, Mean Absolute Error, Mean Square Error, Health BPJS at Jambi.

\section{PENDAHULUAN}

Di Indonesia pemerintah sudah menjalankan program Jaminan Kesehatan Nasional (JKN) pada awal tahun 2018 yang mengacu pada Peraturan Menteri Kesehatan (PMK) No. 28 Tahun 2018 tentang pedoman pelaksanaan JKN. Menurut (JKN), Pemerintah bertanggung jawab atas pelaksanaan jaminan kesehatan masyarakat melalui Jaminan Kesehatan Nasional (JKN). Usaha ke arah itu sesungguhnya telah dirintis pemerintah dengan menyelenggarakan beberapa bentuk jaminan sosial di bidang kesehatan, diantaranya adalah melalui PT Askes (Persero) dan PT Jamsostek (Persero). Untuk masyarakat miskin dan tidak mampu, pemerintah memberikan jaminan melalui Jaminan Kesehatan Masyarakat (Jamkesmas) dan Jaminan Kesehatan Daerah (Jamkesda). Jenis - jenis program 
tersebut masih belum efektif dan efisien. Karna masih banyak masyarakat yang mengeluh dengan pelayanan serta biaya yang dikenakan oleh program JKN tersebut.

Di Provinsi Jambi semua rumah sakit umum daerah ataupun swasta sudah bekerjasama dengan BPJS. Dimana semua rumah sakit wajib membantu masyarakat dalam hal apapun dengan tidak membeda bedakannya. Di salah satu rumah sakit umum yang menjadi pusat rumah sakit di Jambi yaitu RSUD RD MATAHER. Berdasarkan wawancara dengan salah satu masyarakat yang pernah mendapatkan pelayanan di RSUD RD MATAHER mengatakan "Berbagai macam kendala ditemukan di RSUD RD MATAHER ini seperti pelayanan, fasilitas dan pembayaran klaim". Diketahui bahwa kasus keterlambatan pembayaran klaim rawat inap pasien oleh BPJS Kesehatan juga terlihat pada RSUD RD MATAHER Jambi. Penelitipun juga melakukan wawancara dengan salah satu staf pegawai BPJS Kesehatan Kota Jambi yang mengatakan "RSUD RD MATAHER sering lama untuk mengajukan klaim kepada pihak BPJS Kesehatan, dan mengalami keterlambatan pembayaran klaim dikarenakan masih banyak dokumen atau berkas pasien yang belum lengkap sehingga dari pihak BPJS Kesehatan Kota Jambi sendiri juga belum bisa menyetujui untuk memproses lebih lanjut'.

Dimana salah satu metode peramalan yang digunakan adalah metode exponential smoothing. Metode exponential smoothing adalah prosedur perbaikan yang dilakukan secara terus-menerus pada peramalan terhadap data yang terbaru. Metode Exponential Smoothing juga merupakan metode yang dapat digunakan dalam berbagai variasi pola data. Metode ini merupakan metode peramalan yang cukup baik untuk peramalan jangka panjang dan jangka menengah, terutama pada tingkat operasional suatu perusahaan (Sudrimo, S. 2016).

Tujuan Penelitian ini adalah untuk mendapatkan hasil peramalan pasien rawat inap golongan PNS \& NON PNS kelas 1 dan 2 di RSUD RD MATAHER Jambi yang mengajukan Klaim ke BPJS pada priode selanjutnya dengan metode exponential smoothing dari Brown dan Holt. Mengetahui perbandingan metode pemulusan exponential ganda Holt dengan metode pemulusan exponential ganda brown untuk mencari nilai kesalahan terkecil pada peramalan jumlah klaim di BPJS Kesehatan Kota Jambi.

\section{METODE PENELITIAN}

Jenis data yang digunakan dalam penelitian ini berupa data sekunder. Data sekunder merupakan Sumber data yang tidak langsung memberikan data kepada pengumpul data. data yang diperoleh melalui media perantara atau secara tidak langsung yang berupa buku, catatan, buku yang telah ada, atau arsip baik yang dipublikasikan mau pun tidak dipublikasikan secara umum (Sugiyono, 2005). Data yang dikumpulkan dalam penelitian ini adalah data yang diperoleh dari kantor BPJS kesehatan cabang Jambi, yaitu data jumlah pasien rawat inap di RSUD RD MATAHER jambi yang mengajukan klaim ke BPJS Kesehatan Kota Jambi periode Januari 2018 hingga Juli 2021. Dimana data digolongkan menjadi dua yaitu pasien rawat inap PNS dan Non PNS. Studi literatur juga dilakukan yaitu dengan mempelajari buku-buku, jurnal, artikel, serta bahan-bahan dari internet lainnya yang berhubungan dengan metode peramalan khususnya metode exponential smoothing. 


\section{Analisis Data} berikut:

Dalam penelitian ini analisis data dilakukan denagan tahapan sebagai

a. Identifikasi Data untuk mengetahui pola data. Diamana Data yang sudah ada diplot dengan menggunakan aplikasi minitab. Setalah itu akan terlihat grafik yang dihasilkan, kemudian akan ditentukan penggunaan metode exponential smoothing yang tepat.

b. Melakukan pemodelan dengan metode exponential smoothing yang tepat. Setelah diplot data maka didapatlah metode yang tepat untuk plot data klaim tersebut. Dimana metode exponential smoothing terbagi tiga single, double, dan tripel.

c. Melakukan peramalan dengan metode double exponential smoothing dari Brown dan Holt. Karna plot data kliam berpola trend makan metode double exponential smoothing dapat digunakan. Adapun persamaan dari DES Brown dan Holt yaitu :

Peramaan Brown yaitu : $F_{t+m}: a_{t}+b_{t} m$

Dimana $F_{t+m}$ : Nilai Ramalan Klaim untuk periode kedepannya,

$m$ : Jumlah periode ke depan yang akan diramalkan,

$a_{t} \quad$ : Konstanta pemulusan

$b_{t} \quad$ : Konstanta pemulusan atau pengukuran slope suatu kurva

Persamaan Holt yaitu $F_{t+m}: S_{t}+b_{t} m$

Dimana $F_{t+m}$ : Nilai Ramalan Klaim untuk periode kedepannya

$m$ : Jumlah periode ke depan yang akan diramal

$S_{t} \quad$ : Nilai Pemulusan Klaim

$b_{t} \quad$ : Estimasi trend

d. Evaluasi hasil peramalan dengan uji ketepatan peramalan.

Mean Absolute Error (MAE)

Mean Squared Error (MSE).

$$
M A E: \sum_{t=1}^{t} \frac{\left|X_{t}-F_{t}\right|}{n}
$$

Dimana :

$$
M S E: \sum_{t=1}^{n} \frac{\left(X_{t}-F_{t}\right)^{2}}{n}
$$

$X_{t}$ : Nilai Data aktual pada periode ke $\mathrm{t}$

$F_{t}:$ Nilai Ramalan periode ke $\mathrm{t}$

$n$ : Banyaknya data

e. Melihat nilai MAE dan MSE terkecil dari $\alpha$ dan $\gamma$ untuk kedua metode.

f. Membandingkan MAE dan MSE dengan memilih nilai yang paling kecil dari kedua metode.

g. Pemilihan metode yang tepat.

h. Menarik kesimpulan 


\section{HASIL DAN PEMBAHASAN}

\section{Analisis Deskriptif}

Berdasarkan Data Badan Penyelenggara Jaminan Sosial (BPJS) Kesehatan Kota Jambi dari periode Januari 2018 - Juli 2021 jumlah pasien rawat inap di RS RD MATAHER yang mengajukan Klaim dengan dua golongan yaitu PNS Kelas 1 dan NON PNS Kelas 1, PNS Kelas 2 dan NON PNS Kelas 2 adalah sebagai berikut :

\section{Kasus Klaim PNS Kelas 1}

Adapun golongan PNS Kelas 1 ini merupakan golongan pasien yang Pegawai Negeri Sipil di Jambi, yang mendapatkan penanganan dengan Kelas Nomor 1 atau VIP. Adapun garfik Kasus Klaim PNS Kelas 1 sebagai berikut :

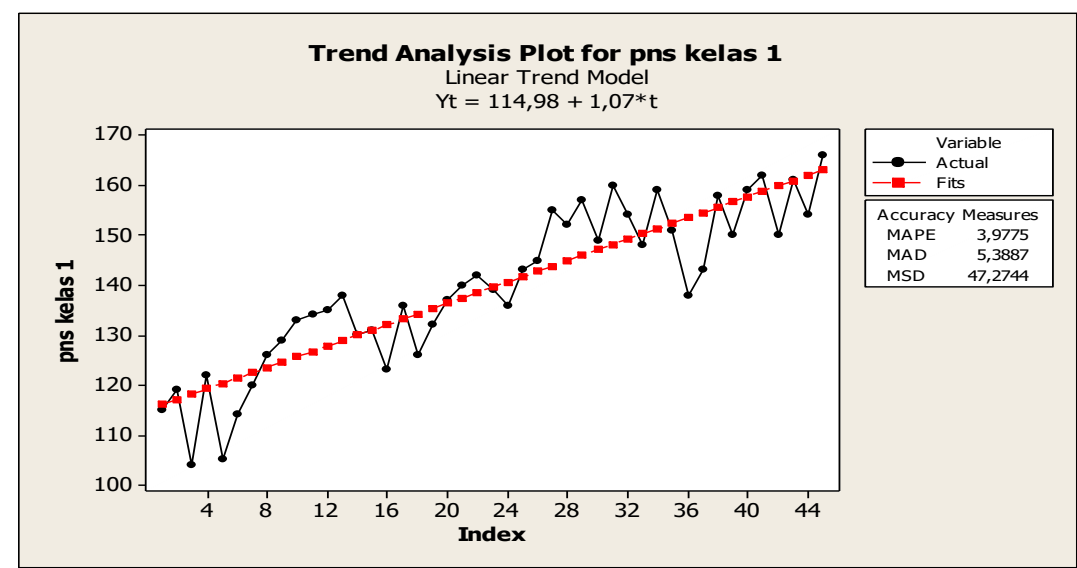

Gambar 1. Grafik Jumlah Kasus Klaim PNS Kelas 1 periode Januari 2018- Juli 2021

Gambar 1 merupakan grafik dari data kasus pasien rawat inap di RS RD MATAHER mengajukan klaim pada BPJS Kesehatan Kota Jambi golongan PNS Kelas 1 periode januari 2018 sampai Juli 2021. Dapat dilihat dari grafik data tersebut mengalami peningkatan dan penurunan yang tidak terlalu jauh dari bulan sebelunya. Dapat dilihat bahwa kasus klaim pada PNS Kelas 1 setiap bulan mengalami kenaikan mulai dari bulan Januari sampai bulan Desember 2018. Akan tetapi, pada tahun Januari 2019 kasus Klaim di RS RD MATAHER mengalami penurunan dan meningkat lagi pada awal Januari 2020. Sementara itu pada Januari 2021 mengalami peningkatan sedikit demi sedikit dari bulan sebelumnya.

\section{Kasus Klaim PNS Kelas 2}

Adapun golongan PNS Kelas 2 ini merupakan golongan pasien yang Pegawai Negeri Sipil di Jambi, yang mendapatkan penanganan dengan Kelas Nomor 2 atau Kelas bawah. Adapun garfik Kasus Klaim PNS Kelas 2 senagai berikut : 


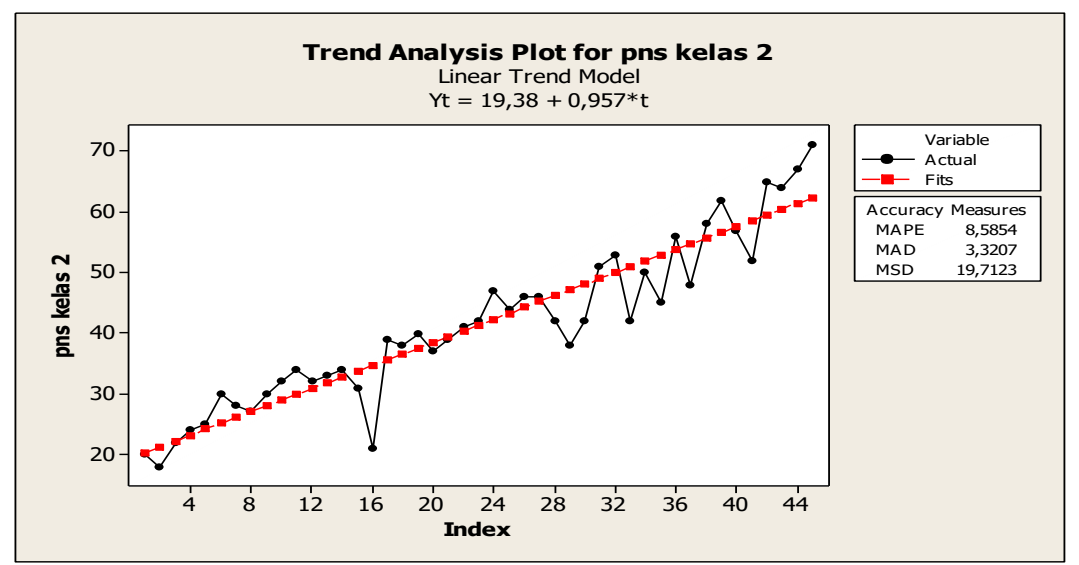

Gambar 2. Grafik Jumlah Kasus Klaim PNS Kelas 2 periode Januari 2018 Juli 2021

Gambar 2 merupakan grafik dari data kasus pasien rawat inap di RS RD MATAHER mengajukan klaim pada BPJS Kesehatan Kota Jambi golongan PNS Kelas 2 periode januari 2018 sampai Juli 2021. Dapat dilihat dari grafik data tersebut mengalami peningkatan dan penuruna yang tidak terlalu signifikan. Dapat dilihat bahwa kasus klaim pada PNS Kelas 2 setiap bulan mengalami kenaikan mulai dari bulan Januari sampai bulan Desember 2018. Akan tetapi, pada tahun Januari 2019 kasus Klaim di RS RD MATAHER mengalami meningkat dan sedikit menurun pada April 2019 lalu meningkat lagi pada awal Januari 2020. Sementara itu pada Januari 2021 mengalami peningkatan sedikit demi sedikit dari bulan sebelumnya sampai dengan bulan Juli 2021 yang lalu dengan jumlah kasus 71 Orang.

\section{Kasus Klaim NON PNS Kelas 1}

Adapun golongan NON PNS Kelas 1 ini merupakan golongan Swasta atau masyarat umum di Jambi, yang mendapatkan penanganan dengan Kelas Nomor 1 atau Kelas VIP. Adapun grafik Kasus Klaim NON PNS Kelas 1 sebagai berikut :

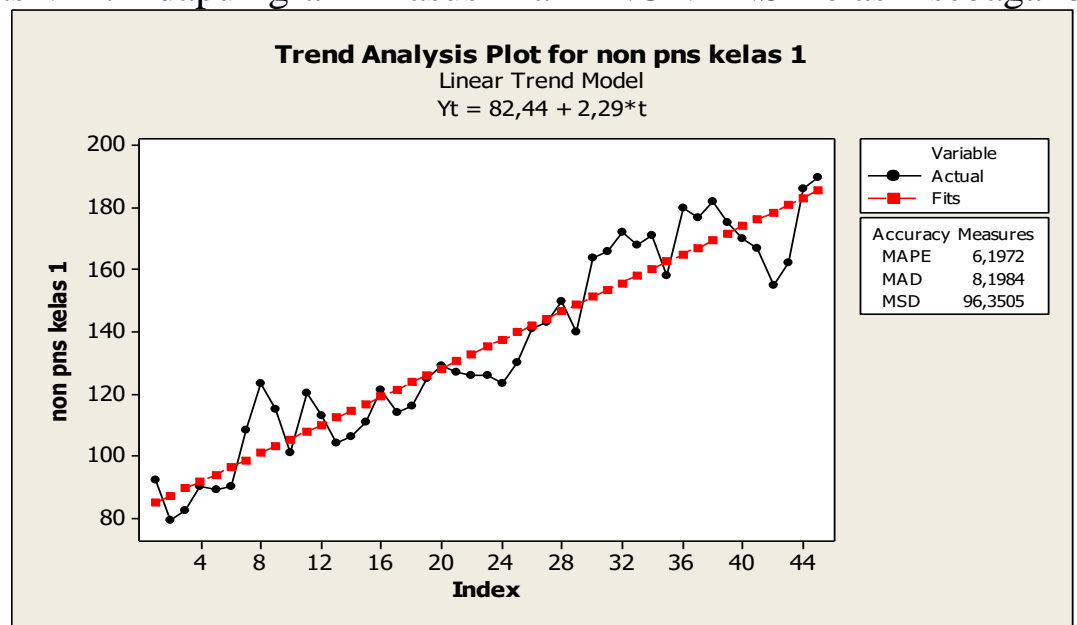

Gambar 3. Grafik Jumlah Kasus Klaim NON PNS Kelas 1 periode Januari 2018Juli 2021

Gambar 3. merupakan grafik dari data kasus pasien rawat inap di RS RD MATAHER mengajukan klaim pada BPJS Kesehatan Kota Jambi golongan NON PNS Kelas 1 periode januari 2018 sampai Juli 2021. Dapat dilihat dari grafik data 
tersebut awal bulan Januari 2018 sampai Desember 2015 mengalami kenaikan yang stabil setiap bulannya. Akan tetapi, pada tahun Januari 2020 kasus Klaim di RS RD MATAHER mengalami meningkat dan sedikit menurun pada November 2020 lalu meningkat lagi pada awal Januari 2021. Sementara itu pada Januari 2021 mengalami peningkatan sedikit demi sedikit dari bulan sebelumnya sampai dengan bulan Juli 2021 yang lalu dengan jumlah kasus 190 Pasien dengan kasus terbanyak di kelas 1 NON PNS ini.

\section{Kasus Klaim NON PNS Kelas 2}

Adapun golongan NON PNS Kelas 2 ini merupakan golongan Swasta atau masyarat biasa di Jambi, yang mendapatkan penanganan dengan Kelas Nomor 1 atau Kelas VIP. Adapun garfik Kasus Klaim NON PNS Kelas 2 sebagai berikut :

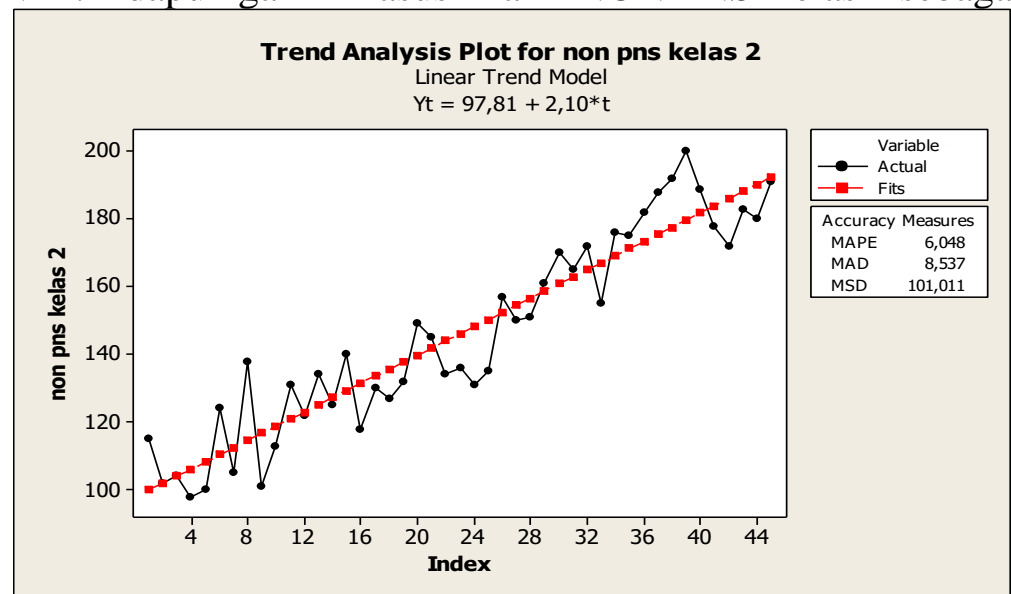

Gambar 4. Grafik Jumlah Kasus Klaim NON PNS Kelas 2 periode Januari 2018Juli 2021

Gambar 4 merupakan grafik dari data kasus pasien rawat inap di RS RD MATAHER mengajukan klaim pada BPJS Kesehatan Kota Jambi golongan NON PNS Kelas 1 periode Januari 2018 sampai Juli 2021. Dapat dilihat dari grafik data tersebut awal bulan Januari 2018 kasus klaim 115 pasien dan menrun Februari Maret April Mei yaitu 102, 104, 98, 100 dan meningkat lagi di bulan Juni menjadi 124 pasien. Tahun 2018 jumlah klaim mengalami penuruan an peningkatan dengan selisih sedikit. Akan tetapi, pada tahun Januari 2016 sampai Januari 2021 kasus Klaim di RSUD RD MATAHER mengalami meningkat yang signifikan dan kasus terbanyak pada Maret 2021 sebanyak 200 pasien. Dan pada bulan berikutnya mengalami penurunan yang tidak jauh dari bulan sebelumnya. Tetapi grafik data Klaim NON PNS kelas 2 tersebut tidak ada terlihat Musiman namun adanya teren naik dan turun, Maka dari itu Metode Pemulusan Eksponetial dapat digunaan untuk kasus data tersebut.

\section{Perbandingan Peramalan Double Exponential Smoothing Dari Brown dan Double Exponential Smoothing dari Holt}

Ketepatan (accuracy) dari suatu metode peramalan merupakan kesesuaian dari suatu metode yang menunjukkan seberapa jauh model peramalan tersebut mampu mereproduksi data yang telah diketahui. Dalam pemodelan deret berkala, sebagian data yang diketahui dapat digunakan untuk meramalkan sisa data berikutnya sehingga memungkinkan orang untuk mempelajari ketepatan peramalan (Makridakis. 1999). Dalam pemilihan metode peramalan perlu dipertimbangkan nilai kesalahan suatu metode peramalan tersebut. 
Hasil yang diperoleh perbandingan nilai forecast error terkecil diperoleh dengan menggunakan Metode Double Exponential Smoothing dari Holt. Karna Semakin besar nilai $\alpha$ yang digunakan akan diperoleh nilai forecast error yang lebih kecil. Sebaliknya semakin kecil $\gamma$ yang digunakan akan dipeoleh nilai forecast error yang lebih kecil. Untuk Metode Double Exponential Smoothing dari Brown kita dapat melihat nilai $\alpha$ nya, semakin besar nilai $\alpha$ yang digunakan maka semakin besar perhitungan nilai error nya. Untuk membandingkan kedua metode tersebut hal ini dapat dilihat dengan nilai error MAE nya pada setiap $\alpha$ dengan kedua metode. Setelah mendapatkan masingmasing $\alpha$ terkecil dari kedua metode lalu bandingkan nilai error MAE dan MSE nya dari masing - masing kasus pada data penelitian.

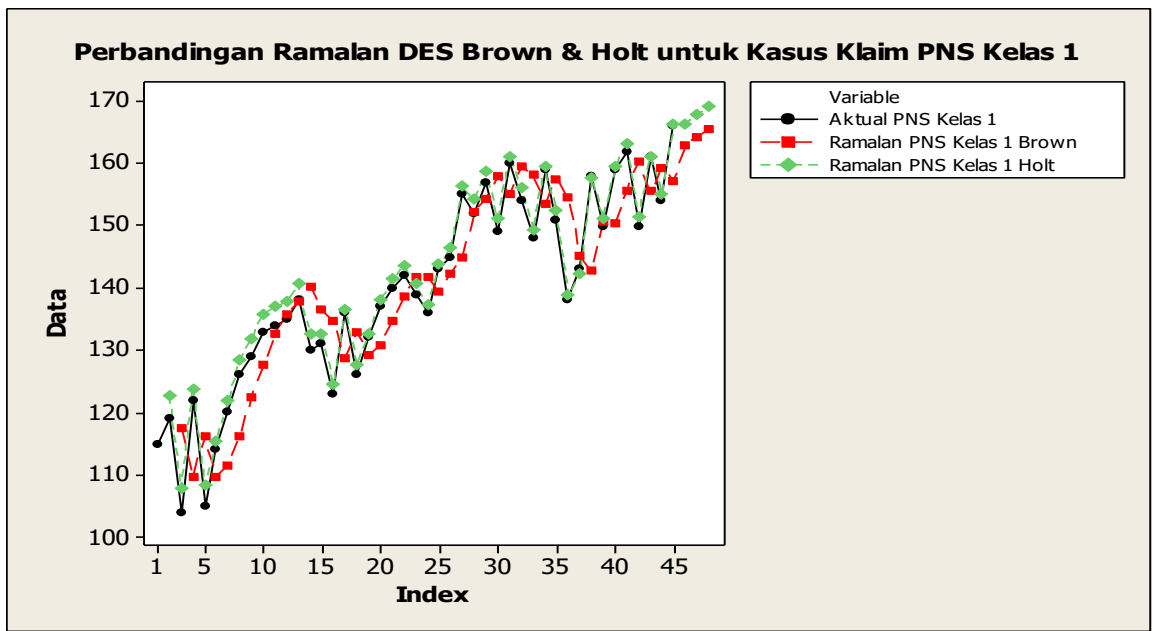

Gambar 5. Grafik Perbandingan Ramalan DES Brown \& Holt untuk Kasus Klaim PNS Kelas 1 Periode Januari 2018-Juli 2021

Berdasarkan grafik perbandingan di atas dapat dilihat bahwa grafik dengan garis hitam itu merupakan data aktual dari Klaim PNS Kelas 1 BPJS Kesehatan Kota Jambi. Garis merah merupakan hasil ramalan klaim PNS Kelas 1 dengan menggunakan metode double exponential smoothing dari Brown, sedangkan garis hijau merupakan hasil ramalan klaim PNS Kelas 1 dengan menggunakan metode double exponential smoothing dari Holt. Dapat dilihat dari kedua metode tersebut memiliki hasil ramalan yang hampir mendekati data aktualnya, dan disini untuk membandingkannya dilihat dari ketepatan error terkecilnya daritode kedua metode tersebut. Dimana telah didapatkan error MAE double exponential smoothing dari holt lebih kecil dari pada error MAE dari Brown. 


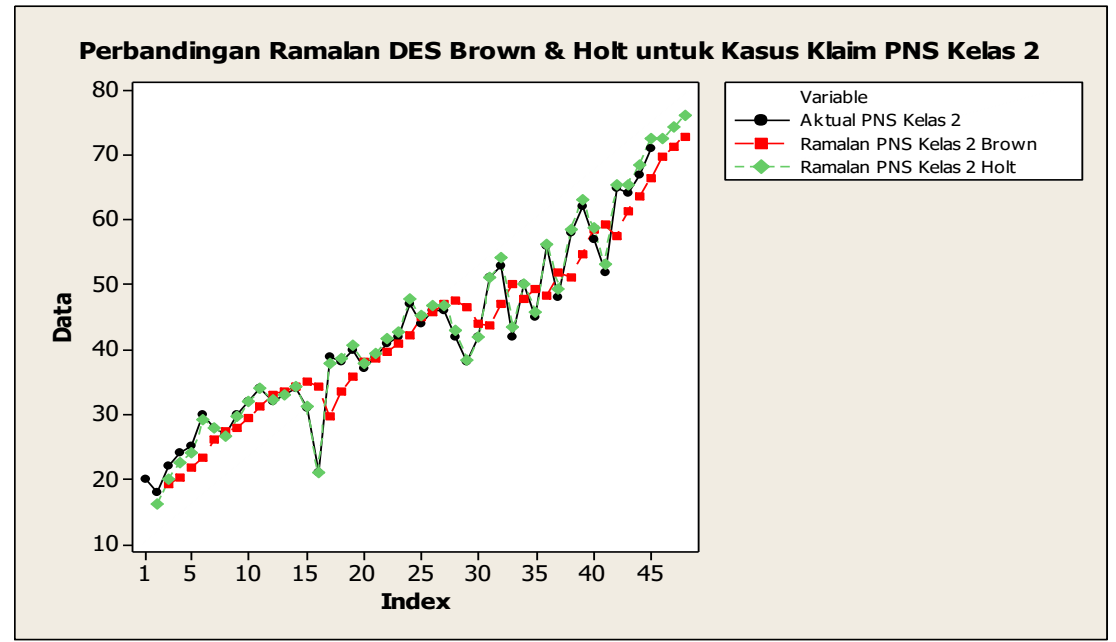

Gambar 6. Grafik Perbandingan Ramalan DES Brown \& Holt untuk Kasus Klaim PNS Kelas 2 Periode Januari 2018-Juli 2021

Berdasarkan grafik perbandingan di atas dapat dilihat bahwa grafik dengan garis hitam itu merupakan data aktual dari Klaim PNS Kelas 2 BPJS Kesehatan Kota Jambi. Garis merah merupakan hasil ramalan klaim PNS Kelas 2 dengan menggunakan metode double exponential smoothing dari Brown, sedangkan garis hijau merupakan hasil ramalan klaim PNS Kelas 2 dengan menggunakan metode double exponential smoothing dari Holt. Dapat dilihat dari kedua metode tersebut memiliki hasil ramalan yang hampir mendekati data aktualnya, dan disini untuk membandingkannya dilihat dari ketepatan error terkecilnya daritode kedua metode tersebut. Dimana telah didapatkan error MAE double exponential smoothing dari holt lebih kecil dari pada error MAE dari Brown.

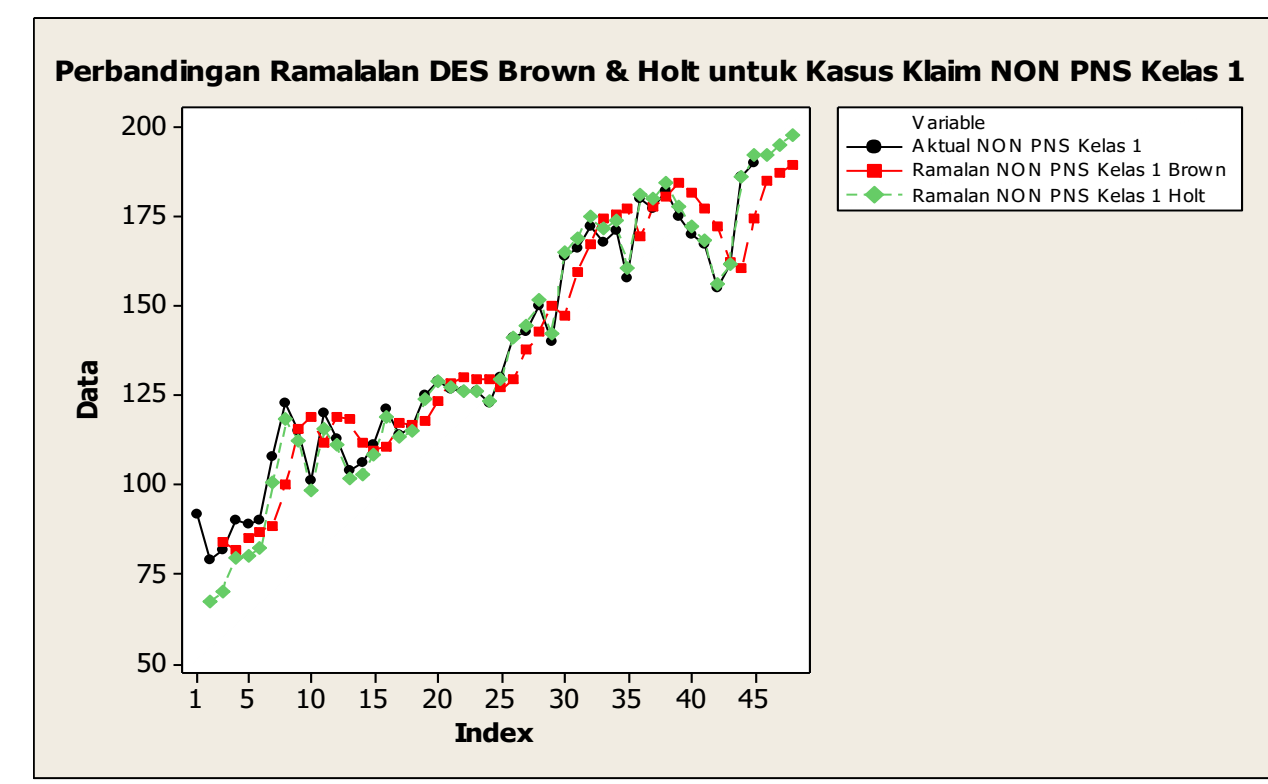

Gambar 7. Grafik Perbandingan Ramalan DES Brown \& Holt untuk Kasus Klaim NON PNS Kelas 1 Periode Januari 2018-Juli 2021

Berdasarkan grafik perbandingan di atas dapat dilihat bahwa grafik dengan garis hitam itu merupakan data aktual dari Klaim NON PNS Kelas 1 BPJS 
Kesehatan Kota Jambi. Garis merah merupakan hasil ramalan klaim NON PNS Kelas 1 dengan menggunakan metode double exponential smoothing dari Brown, sedangkan garis hijau merupakan hasil ramalan klaim NON PNS Kelas 1 dengan menggunakan metode double exponential smoothing dari Holt. Dapat dilihat dari kedua metode tersebut memiliki hasil ramalan yang hampir mendekati data aktualnya, dan disini untuk membandingkannya dilihat dari ketepatan error terkecilnya daritode kedua metode tersebut. Dimana telah didapatkan error MAE double exponential smoothing dari holt lebih kecil dari pada error MAE dari Brown.

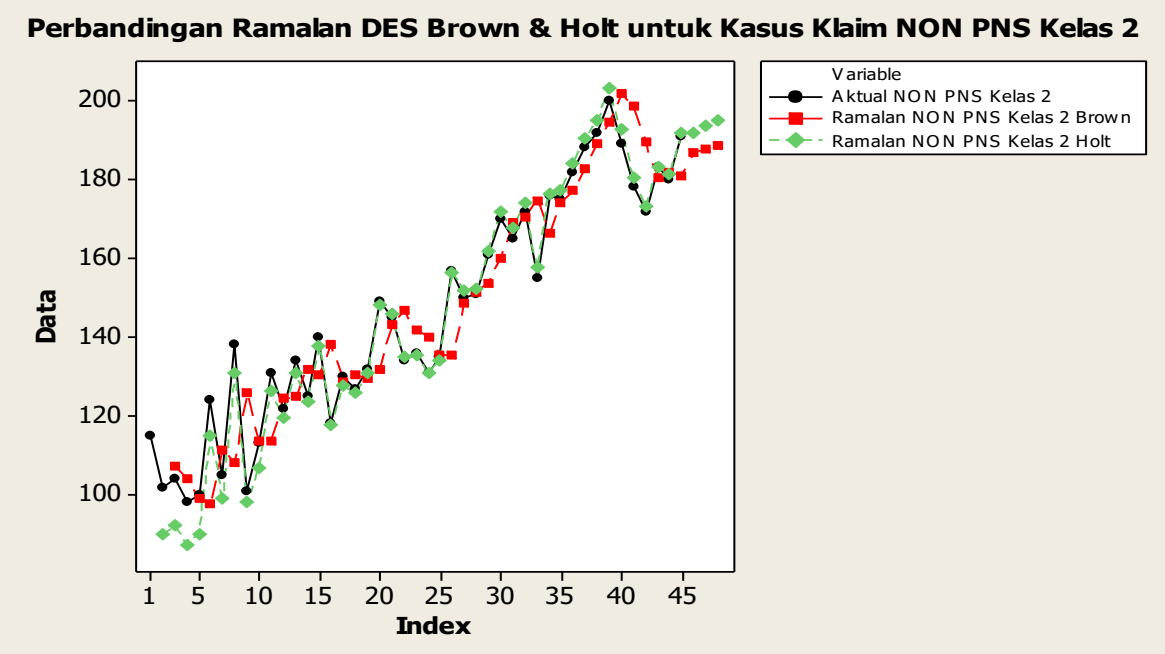

Gambar 8. Grafik Perbandingan Ramalan DES Brown \& Holt untuk Kasus Klaim NON PNS Kelas 2 Periode Januari 2018-Juli 2021

Berdasarkan grafik perbandingan di atas dapat dilihat bahwa grafik dengan garis hitam itu merupakan data aktual dari Klaim NON PNS Kelas 2 BPJS Kesehatan Kota Jambi. Garis merah merupakan hasil ramalan klaim NON PNS Kelas 2 dengan menggunakan metode double exponential smoothing dari Brown, sedangkan garis hijau merupakan hasil ramalan klaim NON PNS Kelas 2 dengan menggunakan metode double exponential smoothing dari Holt. Dapat dilihat dari kedua metode tersebut memiliki hasil ramalan yang hampir mendekati data aktualnya, dan disini untuk membandingkannya dilihat dari ketepatan error terkecilnya daritode kedua metode tersebut. Dimana telah didapatkan error MAE double exponential smoothing dari holt lebih kecil dari pada error MAE dari Brown.

Tabel 1. Perbandingan Peramalan Nilai Ketepatan Error Kedua Metode

\begin{tabular}{|c|c|c|c|c|}
\hline \multirow{2}{*}{ Kategori } & \multicolumn{2}{|c|}{ Brown } & \multicolumn{2}{|l|}{ Holt } \\
\hline & MAE & MSE & MAE & MSE \\
\hline \multirow{3}{*}{ PNS Kelas 1} & $\alpha=0,3$ & & $\alpha=0,9 \& \gamma=0,1$ & \\
\hline & $=6,257$ & 56,052 & $=1,640$ & 3,515 \\
\hline & $\alpha=0,2$ & & $\alpha=0,9 \& \gamma=0,1$ & \\
\hline PNS Kelas 2 & $=3,801$ & 23,537 & $=0,730$ & 0,804 \\
\hline Non PNS Kelas & $\alpha=0,3$ & & $\alpha=0,9 \& \gamma=0,1$ & \\
\hline 1 & $=7,865$ & 102,091 & $=2,810$ & 17,102 \\
\hline
\end{tabular}


Non PNS Kelas $\quad \alpha=0,3 \quad \alpha=0,9 \& \gamma=0,1$

Dari Tabel 1 di atas dapat dilihat perbandingan peramalan dengan membandingkan nilai ketepatan error nya. Dengan demikian untuk pemilihan Metode terbaik yaitu dengan menggunakan Metode Double Exponential Smoothing dari Holt dengan Ketepatan nilai MAE terkecil. Adapun perbandingan nilai MAE dan MSE sebagai berikut :

Kasus klaim PNS Kelas 1 dari brown dengan $\alpha=0,3$ nilai MAE $=6,257$ dan MSE $=56,052$. Untuk PNS Kelas 2 pada $\alpha=0,2$ nilai error 3,801 untuk MAE dan 23,537 untuk MSE. NON PNS Kelas 1 didapat pada $\alpha=0,3$ dengan MAE $=$ 7,865 dan MSE $=102,091$. NON PNS Kelas 2 pada $\alpha=0,3$ dengan MAE $=8,427$ dan MSE $=134,35$.

Kasus Klaim PNS Kelas 1 dari Holt dengan menggunakan $\alpha=0,9$ dan $\gamma=$ 0,1 di dapat nilai MAE $=1,64065$ dan nilai $\mathrm{MSE}=3,5515$ untuk kasus bulan kedepannya mengalami kenaikan yang selisih sedikit dari pada bulan sebelumnya. PNS Kelas 2 dengan menggunakan $\alpha=0,9$ dan $\gamma=0,1$ didapat nilai MAE $=0,730$ dan nilai MSE $=0,804$. NON PNS Kelas 1 dengan menggunakan $\alpha=0,9$ dan $\gamma=$ 0,1 di dapat nilai MAE $=2,810$ dan nilai $\mathrm{MSE}=17,102$. NON PNS Kelas 2 dengan menggunakan $\alpha=0,9$ dan $\gamma=0,1$ didapat nilai $\mathrm{MAE}=1,641$ dan nilai $\mathrm{MSE}=$ 3,5515 .

\section{KESIMPULAN}

Berdasarkan hasil penelitian dan pembahasaan dapat diambil kesimpulan sebagai berikut :

1. Model dari Brown untuk PNS Kelas $1: F_{9+m}=161,65+1,3126 m$, Untuk Oktober $=163$, November $=164,32$, Desember $=165,62$. PNS Kelas 2: $F_{9+m}=67,997+1,635 \mathrm{~m}$, Untuk Oktober $=69,63$, November $=71,27$, Desember $=72,91$. Dan NON PNS Kelas 1: $F_{9+m}=182,5+12,392 m$, Untuk Oktober $=184,89$, November $=187,29$, Desember $=189,68$. NON PNS Kelas $2: F_{9+m}=186+0,831 \mathrm{~m}$, Untuk Oktober 186,81 , November $=$ 187,72 , Desember $=188,55$.

2. Model dari Holt untuk PNS Kelas $1: F_{9+m}=164,917+1,43009 m$, Untuk Oktober 166,34, November $=167,77$, Desember $=169,20$. PNS Kelas 2 : $F_{9+m}=70,736+1,7505 m$, Untuk Oktober 72,48, November $=74,23$, Desember $=75,98$. Dan NON PNS Kelas $1: F_{9+m}=189,59+2,7168 m$, Untuk Oktober $=192,30$, November $=195,02$, Desember $=197,74$. NON PNS Kelas $2: F_{9+m}=190,01+1,703 m$, Untuk Oktober $=191,71$, November $=$ 193,41, Desember $=195,12$.

3. Kedua metode mempunyai kinerja yang sama sama bagus, akan tetapi Metode Double Exponential Smoothing dari Holt lebih memiliki nilai error MAE yang lebih kecil dibandingkan Metode Double Exponential Smoothing dari Brown. Semakin besar nilai $\alpha$ yang digunakan akan diperoleh nilai forecast error yang lebih kecil. Sebaliknya semakin kecil $\gamma$ yang digunakan akan dipeoleh nilai forecast error yang lebih kecil. 


\section{DAFTAR PUSTAKA}

BPJS Kesehatan. Buku Panduan Layanan Bagi Peserta BPJS Kesehatan. -Badan Penyelenggara Jaminan Sosial. Jakarta.

Faisol dkk. (2016). Penerapan Metode Exponential Smoothing untuk Peramalan Jumlah Klaim di BPJS Kesehatan Pamenkeas. Jurnal Matematika Vol. 01. No.01. FMIPA Matematika. Universitas Madura.

Makridakis, S., Wheelwright, S.C., \& McGee, V.E. (1999). Metode dan Aplikasi Peramalan Jilid 1 ( Ir. Untung Sus Ardiyanto, M.Sc. \& Ir. Abdul Basith, M.Sc. Terjemahan). Edisi Kedua. Jakarta: Penerbit Erlangga..

Sudrimo. S. (2016). Peramalan Data Deret Berkala Menggunakan Metode Pemulusan Eksponential Tripel. Skripsi FMIPA Matematika. Universitas Lampung. 